\title{
Cyclin D1 overexpression in Algerian breast cancer women: correlation with CCND1 amplification and clinicopathological parameters
}

\author{
Latifa Mohammedi, Fatima Djilali Doula, Farida Mesli, Rachid Senhadji
}

University of Oran 1 Ahmed Ben Bella, Algeria, Nature and Life Sciences Faculty, BP 1524 El M'naouer, Oran 31000, Algeria.

\begin{abstract}
Background: Cyclin D1 which is associated with cell cycle regulation is solidly established as an oncogene with an important pathogenetic role in breast carcinomas.

Objectives: The aim of this study was to relate the Cyclin D1 protein overexpression with the amplification of its gene CCND1 in Estrogen Receptors (ER) positive breast carcinomas, in order to investigate the prognostic effect of their aberrations in relation to ER status, also to correlate the Cyclin D1 overexpression with other prognostic parameters.

Materials and methods: Chromogenic in situ hybridization (CISH) was used to identify CCND1 amplification on formalin-fixed paraffin-embedded invasive ductal carcinoma, in which immunohistochemistry (IHC) had previously been performed in order to evaluate the pathological relevance of Cyclin D1 overexpression in human breast cancer $(\mathrm{n}=138)$.

Results: CCND1 amplification was identified in 17/138 (12.3\%) tumors and 78/138 (56.5\%) tumors have overexpressed Cyclin D1. A significant correlation was identified between CCND1 amplification and Cyclin D1 overexpression $(\mathrm{P}<0.001)$ and both Cyclin D1 and CCND1 were related with ER expression.

Conclusion: Our results show a significant correlation between Cyclin D1 overexpression and CCND1 amplification. Overexpression of Cyclin D1was observed in high proportion of breast cancer which should be considered for routine diagnosis.

Keywords: Cyclin D1, CCND1, breast cancer, immunohistochemistry, CISH.

DOI: https://dx.doi.org/10.4314/ahs.v19i2.38

Cite as: Mohammedi L, Doula FD, Mesli F, Senhadji R. Cyclin D1 over expression in Algerian breast cancer women: Correlation with CCND1 amplification and clinicopathological parameters. Afri Health Sci.2019;19(2): 2140-2146. bttps:// dx.doi.org/10.4314/ahs.v19i2.38
\end{abstract}

\section{Introduction}

Gene amplification is a frequent device leading to the overexpression of oncogenes in human cancers ${ }^{1}$. Cyclin $\mathrm{D} 1$ is the product of the CCND1 gene located on chromosome $11 \mathrm{q}^{2} 3^{2}$. Cyclin D1, an important regulator of the cell cycle, ${ }^{3,4}$ has been reported in $40 \%$ to $90 \%$ of invasive breast cancer cases ${ }^{4-6}$ and its gene has been found amplified in 15-20\% of breast cancers ${ }^{7-9}$. These facts are well established and indicate that mechanisms other than gene amplification are responsible for deregulation of the protein. In addition to its role in cell cycleregulation, Cyclin D1 can regulate the growth of estrogen respon-

\section{Corresponding author: \\ Latifa Mohammedi, \\ University of Oran 1 Ahmed Ben Bella, Algeria, Nature and Life Sciences Faculty, BP 1524 El M'naouer, Oran 31000, Algeria. Email: latifabio2@gmail.com}

sive tissues by activating the estrogen receptor (ER) in a ligand-independent fashion ${ }^{10}$. The induction of Cyclin D1 in breast cancer cell lines generate an increase in the number of cells progressing through G1 and accelerate transition from $\mathrm{G} 1$ to $\mathrm{S}$ phase, indicating that Cyclin D1 is rate-restrictive for progress through G1 phase ${ }^{11}$. This rate-limiting step in cell cycle progression is regulated by a number of mechanisms including Cyclin D1 abundance; consequently, deregulation of Cyclin D1 gene expression or function is a probable contributor to loss of normal cell cycle control during carcinogenesis ${ }^{12}$. 
In this study, Cyclin D1 overexpression was detected by immunohistochemistry and its gene amplification was detected by chromogenic in situ hybridization (CISH). Overexpression of Cyclin D1 protein was also investigated in combination with prognostic marker. The aims of the present study were to determine in the first part, the correlation between Cyclin D1 overexpression and other prognostic parameters, and in second part, to correlate the Cyclin D1 overexpression with the CCND1 amplification in breast carcinomas.

\section{Materials and methods}

The study material consists of 138 invasive ductal breast carcinomas (IDC) from patients diagnosed between January 2011 and September 2015. All patients' tumors were collected from the Regional Military University Hospital. Patient characteristics are summarized in Table 1.

Table 1: Patient and tumor clinicopathological characteristics

\begin{tabular}{|c|c|}
\hline Characteristics & Number of patients (\%) \\
\hline \multicolumn{2}{|l|}{ Age of patients (years) } \\
\hline $30-39$ & $19(13.8)$ \\
\hline $40-49$ & $35(25.4)$ \\
\hline $50-59$ & $38(27.5)$ \\
\hline $60-69$ & $25(18.1)$ \\
\hline$\geq 70$ & $21(15.2)$ \\
\hline \multicolumn{2}{|l|}{ Tumors size $(\mathrm{cm})$} \\
\hline $\mathrm{T} 1(<2 \mathrm{~cm})$ & $11(8)$ \\
\hline $\mathrm{T} 2(2-5 \mathrm{~cm})$ & $101(73.2)$ \\
\hline $\mathrm{T} 3$ and $\mathrm{T} 4(\geq 5 \mathrm{~cm})$ & $26(18.8)$ \\
\hline \multicolumn{2}{|l|}{ SBR grade } \\
\hline $\mathrm{I}$ & $2(1.4)$ \\
\hline II & $87(63.1)$ \\
\hline III & $49(35.5)$ \\
\hline \multicolumn{2}{|l|}{ Lymph node status } \\
\hline Negative & $54(39.1)$ \\
\hline positive & $84(60.9)$ \\
\hline \multicolumn{2}{|l|}{ Estrogen receptor status } \\
\hline Negative & $28(20.3)$ \\
\hline positive & $110(79.7)$ \\
\hline \multicolumn{2}{|l|}{ Progesterone receptor status } \\
\hline Negative & $43(31.2)$ \\
\hline positive & $95(68.8)$ \\
\hline \multicolumn{2}{|c|}{ Ki-67 proliferation marker status } \\
\hline Negative & $46(33.3)$ \\
\hline positive & $92(66.7)$ \\
\hline \multicolumn{2}{|l|}{ Cyclin D1 status } \\
\hline Negative & $60(43.5)$ \\
\hline positive & $78(56.5)$ \\
\hline \multicolumn{2}{|l|}{ CCND1 gene status } \\
\hline Amplified (< 5 copies) & $17(12.3)$ \\
\hline Non-amplified (>5 copies) & $121(87.7)$ \\
\hline
\end{tabular}


Clinicopathological characteristics of the patients like age, SBR grade,tumor size and lymph node status were extracted from the pathology reports. For immunohistochemical analysis, paraffin sections were mounted on APES (2\% 3'-aminopropyltriethoxysilane) coated slides. A monoclonal Mouse antibody Anti-Human Cyclin D1 clone DCS-6, DAKO (provided in liquid form as tissue culture supernatant in $0.05 \mathrm{~mol} / \mathrm{L}$ Tris- $\mathrm{HCl}, \mathrm{pH} 7.6$ and $0.015 \mathrm{~mol} / \mathrm{L}$ sodium azide) was used. The indirect avidin-biotin immunoperoxidase technique was used to demonstrate antibody binding sites. Finally, the sections were lightly counterstained in hematoxylin. Scoring of the Cyclin D1, Ki-67, ER and progesterone receptor (PR) reactivity, was performed by using the Allred method ${ }^{13}$, which classifies tumors into three groups: negative/weak (scores 0-2), moderate (scores 3-5) and strong (scores 6-8).

To analyze the amplification of CCND1, we used chromogenic in situ hybridization (CISH), in which paraffin-embedded tissue sections were fixed in neutral buffered formalin for 12-24 hours before use. Tissue sections (4-5 $\mu \mathrm{m}$ thickness) were mounted on Superfrost/Plus microscope slides. Deparaffinized slides were heated above $98^{\circ} \mathrm{C}$ for $15 \mathrm{~min}$. in tissue heat pre-treatment solution and incubated for enzyme digestion for $10 \mathrm{~min}$. After denaturation and hybridization, CISH staining results were visualized with a standard brightfield microscope and a 40x dry lens. The presence of $\geq 5$ individual signals, within the nuclei of a single cell is indicative of positive reactivity. The statistical analysis was performed using the IBM SPSS Advanced 20.0 statistical software, reference: 5725 -
A54. Correlations of Cyclin D1 and CCND1 to other clinicopathologic parameters were evaluated using Pearson's correlation test $(\mathrm{r})$. $\mathrm{P}$ value $<0.05$ was considered as significant.

\section{Results}

The clinicopathological characteristics of the patients are mentioned in table 1 . The grade SBR II was dominant $(63.1 \%)$. Tumor sizes exceed $2 \mathrm{~cm}$ in $92 \%$ of the patients, and $60.9 \%$ had positive lymph nodes. The immunohistochemical staining showed overexpression of ER and PR in $79.7 \%$ and $68.8 \%$ of cases respectively. $\mathrm{Ki}-67$ was overexpressed in $66.7 \%$ of tumors and Cyclin D1 overexpression was observed in $78(56.5 \%)$ cases. The CCND1 gene was amplified in $17(12.3 \%)$ cases.

The results of the clinicopathological characteristics of the tumors in relation to the expression of Cyclin D1 are shown in Table 2. Cyclin D1 expression was found in 78 $(56.5 \%)$ cases, whose $52.6 \%$ expressed it moderately and $47.4 \%$ were strongly positive. The majority of cases, 53 cases $(67.9 \%)$ were in the $\geq 50$ year age group. The maximum number of cases (51/78) 65.4\% had grade SBR II. (48/78) $61.5 \%$ cases had positive lymph nodes and $70.5 \%$ of tumors were $>2 \mathrm{~cm}$. There was no significant correlation between overexpression of Cyclin D1 and age of patients $(\mathrm{r}=0.161 / \mathrm{P}=0.060)$, grade SBR $(\mathrm{r}=-0.05 /$ $\mathrm{P}=0.518)$, lymph node status $(\mathrm{r}=-0.01 / \mathrm{P}=0.833)$, size of tumors $(r=0.11 / \mathrm{P}=0.186)$. There was a significant correlation between high Cyclin D1 expression and hormone receptors including ER and PR $(r=0.52 / \mathrm{P}=$ $<0.001$ and $\mathrm{r}=0.26 / \mathrm{P}=0.002)$. Cyclin D1 overexpression was significantly correlated with proliferation marker Ki-67 ( $r=0.19 / \mathrm{P}=0.022)$. 
Table 2: Correlation of Cyclin D1 expression with clinicopathological parameters

\begin{tabular}{|c|c|c|c|c|}
\hline Parameters & $\begin{array}{c}\text { Negative/weak } \\
\text { Cyclin D1 expression }\end{array}$ & $\begin{array}{c}\text { Moderate } \\
\text { Cyclin D1 expression }\end{array}$ & $\begin{array}{l}\text { Strong Cyclin } \\
\text { D1 expression }\end{array}$ & $\mathrm{r} / \mathrm{P}$-values \\
\hline \multicolumn{5}{|c|}{ Age of patients (years) } \\
\hline$<50$ & $29(21 \%)$ & $15(10.9 \%)$ & $10(7.2 \%)$ & $0.161 / 0.060$ \\
\hline$\geq 50$ & $31(22.5 \%)$ & $26(18.8 \%)$ & $27(19.6 \%)$ & \\
\hline \multicolumn{5}{|l|}{ SBR grade } \\
\hline $\mathrm{I}$ & $2(1.4 \%)$ & 0 & 0 & $-0.05 / 0.518$ \\
\hline II & $36(26.1 \%)$ & $23(16.7 \%)$ & $28(20.3 \%)$ & \\
\hline III & $22(15.9 \%)$ & $18(13.1 \%)$ & $9(6.5 \%)$ & \\
\hline \multicolumn{5}{|c|}{ Lymph node status } \\
\hline Negative & $24(17.4 \%)$ & $14(10.1 \%)$ & $16(11.6 \%)$ & $-0.01 / 0.833$ \\
\hline Positive & $36(26.1 \%)$ & $27(19.6 \%)$ & $21(15.2 \%)$ & \\
\hline \multicolumn{5}{|c|}{ Tumors size (cm) } \\
\hline$<2 \mathrm{~cm}$ & $5(3.6 \%)$ & $5(3.6 \%)$ & $1(0.7 \%)$ & $0.11 / 0.186$ \\
\hline $2-5 \mathrm{~cm}$ & $46(33.3 \%)$ & $28(20.3 \%)$ & $27(19.6 \%)$ & \\
\hline$>5 \mathrm{~cm}$ & $9(6.5 \%)$ & $8(5.8 \%)$ & $9(6.5 \%)$ & \\
\hline \multicolumn{5}{|c|}{ Estrogen receptor status } \\
\hline Negative & $16(11.6 \%)$ & $10(7.2 \%)$ & $2(1.4 \%)$ & $0.52 /<0.001$ \\
\hline Positive & $44(31.9 \%)$ & $31(22.5 \%)$ & $35(25.4 \%)$ & \\
\hline \multicolumn{5}{|c|}{ Progesterone receptor status } \\
\hline Negative & $23(16.7 \%)$ & $12(8.7 \%)$ & $8(5.8 \%)$ & $0.26 / 0.002$ \\
\hline Positive & $37(26.8 \%)$ & $29(21 \%)$ & $29(21 \%)$ & \\
\hline \multicolumn{5}{|c|}{ Ki-67 proliferation marker status } \\
\hline Negative & $25(18.1 \%)$ & $13(9.4 \%)$ & $8(5.8 \%)$ & $0.19 / 0.022$ \\
\hline Positive & $35(25.4 \%)$ & $28(20.3 \%)$ & $29(21 \%)$ & \\
\hline
\end{tabular}

The results of the clinicopathological parameters in relation to the CCND1 status are shown in Table 3. CCND1 amplification was found in $17(12.3 \%)$ cases whose 14 cases presented $>10$ copies of the gene present per nucleus in $>50 \%$ cancer cells. CCND1 was correlated with hormone receptor positivity ER $(r=0.28 / \mathrm{P}=0.003)$ and PR ( $\mathrm{r}=0.22 / \mathrm{P}=0.030)$ while there was no correlation with proliferation marker Ki-67 $(\mathrm{r}=0.15 / \mathrm{P}=$ 0.080). CCND1 amplification was not significantly related in our study to age of patients $(\mathrm{r}=-0.11 / \mathrm{P}=0.202)$, SBR grade $(\mathrm{r}=-0.07 / \mathrm{P}=0.361)$, lymph node status $(\mathrm{r}=$ $-0.01 / \mathrm{P}=0.855)$ and tumors size $(\mathrm{r}=0.05 / \mathrm{P}=0.559)$.

\section{Parameters}

Correlation of Cyclin D1 expression with CCND1 amplification:

Gene amplification of CCND1 was observed in moderate and strong Cyclin D1 expression subgroups (Table 4). Among the 17 patients with amplification of CCND1 (>5 copies), $13(76.5 \%)$ showed a strong expression of Cyclin D1, whereas 4/17 showed moderate expression. Tumors with non-amplified CCND1 gene were also observed in moderate and strong sub-groups with low frequencies corresponding to $30.6 \%$ and $19.8 \%$ respectively. A good association was found between CCND1 amplification and Cyclin D1 overexpression (Table 4, P $<0.001)$. This correlation was very high $(\mathrm{r}=0.42 / \mathrm{p}<$ $0.0001)$ in hormone receptor-positive tumors. 
Table 3: Correlation of CCND1 amplification with clinicopathological parameters

\begin{tabular}{|c|c|c|c|}
\hline Parameters & CCND1 non-amplified & CCND1 amplified & $\mathrm{r} / \mathrm{P}$-values \\
\hline \multicolumn{4}{|c|}{ Age of patients (years) } \\
\hline$<50$ & $46(33.3 \%)$ & $8(5.8 \%)$ & \multirow[t]{2}{*}{$-0.11 / 0.202$} \\
\hline$\geq 50$ & $75(54.4 \%)$ & $9(6.5 \%)$ & \\
\hline \multicolumn{4}{|l|}{ SBR grade } \\
\hline I & $2(1.4 \%)$ & 0 & \multirow[t]{3}{*}{$-0.07 / 0.361$} \\
\hline II & $74(53.6 \%)$ & $13(9.4 \%)$ & \\
\hline III & $45(32.6 \%)$ & $4(2.9 \%)$ & \\
\hline \multicolumn{4}{|c|}{ Lymph node status } \\
\hline negative & $47(34.1 \%)$ & $7(5.1 \%)$ & \multirow[t]{2}{*}{$-0.01 / 0.855$} \\
\hline Positive & $74(53.6 \%)$ & $10(7.2)$ & \\
\hline \multicolumn{4}{|c|}{ Tumors size (cm) } \\
\hline$<2 \mathrm{~cm}$ & $11(8 \%)$ & 0 & \multirow[t]{3}{*}{$0.05 / 0.559$} \\
\hline $2-5 \mathrm{~cm}$ & $87(63 \%)$ & $14(10.1 \%)$ & \\
\hline$>5 \mathrm{~cm}$ & $23(16.7 \%)$ & $3(2.2 \%)$ & \\
\hline \multicolumn{4}{|c|}{ Estrogen receptor status } \\
\hline negative & $25(18.1 \%)$ & $3(2.2 \%)$ & \multirow[t]{2}{*}{$0.28 / 0.003$} \\
\hline Positive & $96(69.6 \%)$ & $14(10.1 \%)$ & \\
\hline \multicolumn{4}{|c|}{ Progesterone receptor status } \\
\hline negative & $39(28.3 \%)$ & $4(2.9 \%)$ & \multirow[t]{2}{*}{$0.22 / 0.030$} \\
\hline Positive & $82(59.5 \%)$ & $28(20.3 \%)$ & \\
\hline \multicolumn{4}{|c|}{ Ki-67 proliferation marker status } \\
\hline negative & $43(31.2 \%)$ & $3(2.2 \%)$ & \multirow[t]{2}{*}{$0.15 / 0.080$} \\
\hline Positive & $78(56.5 \%)$ & $14(10.1 \%)$ & \\
\hline
\end{tabular}

Table 4: Correlation of Cyclin D1 expression with CCND1 amplification.

\begin{tabular}{|c|c|c|c|c|}
\hline \multicolumn{5}{|c|}{ Cyclin D1 expression } \\
\hline Parameters & Negative/weak & Moderate & Strong & $\mathrm{r} / \mathrm{P}$-values \\
\hline CCND1 gene status & & & & $0.42 /<0.001$ \\
\hline Non-amplified ( $<5$ copies) & $60(49.6 \%)$ & $37(30.6 \%)$ & $24(19.8 \%)$ & \\
\hline Amplified ( $>5$ copies) & 0 & $4(23.5 \%)$ & $13(76.5 \%)$ & \\
\hline
\end{tabular}




\section{Discussion}

In the present study, we have firstly examined the $\mathrm{Cy}$ clin D1 expressions by IHC and correlate it with ER, PR, $\mathrm{Ki}-67$ and other clinicopathological parameters, on the other hand, we examined by CISH the copies number of CCND1 gene in invasive ductal breast cancer in relation to Cyclin D1 protein expression.

Cyclin D1 is necessary for the normal development of the breast and dysregulated expression stimulates aberrant mammary epithelial proliferation ${ }^{14}$. In the current study, Cyclin D1 overexpression was found in $56.5 \%$ of cases which is in concordance with many of the similar studies $^{15-17}$ who showed that Cyclin D1 was overexpressed in 60\% - 63.4\% of breast carcinomas. We found that Cyclin D1 was significantly correlated with ER+ breast cancer, these results is comparable to other study ${ }^{6,18}$ on invasive breast carcinoma where they found a positive correlation of Cyclin D1 overexpression with ER expression. This can be explained by the positive regulation of ER by Cyclin D1 in breast cancer cell lines where Cyclin D1 has been shown to join directly and activate the estrogen receptor alpha (ER) in a cdk- and pRB-independent fashion $^{10,19}$. This finding, that overexpressed Cyclin D1 can activate the ER independently, has the potential to add a crucial dimension to our understanding of mammary carcinogenesis ${ }^{20-22}$. In the current study, we found a significant correlation between Cyclin D1 and Ki-67, which is linked to a more aggressive tumor phenotype, these results are is in accordance with a previous study ${ }^{23}$ who believe that tumors with overexpression of Cyclin D1 have a higher growth potential and favor the progression of the cell cycle more easily resulting in the overexpression of $\mathrm{Ki}-67$.

The other clinicopathological parameters like SBR grade, tumor size and lymph nodes status were no correlated with Cyclin D1 overexpression in our study; this is in agreement with previous studies ${ }^{18,24,25}$ demonstrating that no significant association between these parameters and Cyclin D1 overexpression.

Given that amplification of CCND1 is one of the reasons for Cyclin D1 overexpression in breast cancer, we have tried to correlate them. We found an excellent correlation between CCND1 amplification and Cyclin D1 overexpression, particularly in ER+ tumors; this result is in agreement with many previous studies ${ }^{6,15,16,18}$.

\section{Conclusion}

Our results confirmed a high correlation of Cyclin D1 expression and CCND1 amplification in ER+ breast cancer; hence it would be useful to identify a subset of patients with ER+ breast cancer for which CCND1 amplification should be considered for diagnosis and treatment.

Our results also showed that high expression of Cyclin D1 is not always resulting to CCND1 amplification suggesting that its association with other clinicopathological parameters is also responsible for this overexpression. Finally, because of its established role as a major human oncogene, direct targeting of the Cyclin D1 protein or CCND1 gene may prove successful.

\section{Conflict of interest}

None.

\section{References}

1. Brown LA, Johnson K, Leung S, Bismar TA, Benitez J, Foulkes W D et al. Co-amplification of CCND1 and EMSY is associated with an adverse outcome in ER-positive tamoxifen-treated breast cancers. Breast Cancer Res Treat. 2010; 121:347- PubMed ;354.

2. Rakha EA, Green AR, Powe DG, Roylance R, Ellis IO. Chromosome 16 tumor-suppressor genes in breast cancer. Genes Chromosomes Cancer. 2006; 45(6):527-535.

3. Baldin V, Lukas J, Marcote MJ, Pagano M, Draetta G. Cyclin D1 is a nuclear protein required for cell cycle progression in G1. Genes Dev. 1993; 7(5):812 PubMed -821.

4. Ormandy CJ, Musgrove EA, Hui R, Daly RJ, Sutherland RL. Cyclin D1, EMS1 and 11q13 amplification in breast cancer. Breast Cancer Res Treat. 2003; 78(3):323-335. 5. Molland JG, Donnellan M, Janu NC, Carmalt HL, Kennedy CW, Gillett DJ. Infiltrating lobular carcinoma - a comparison of diagnosis, management and outcome with infiltrating duct carcinoma. Breast. 2004; 13(5):389-396.

6. Reis-Filho JS, Savage K, Lambros MB, James M, Steele D, Jones RL et al. Cyclin D1 protein overexpression and CCND1 amplification in breast carcinomas: an immunohistochemical and chromogenic in situ hybridization analysis. Mod Pathol. 2006; 19(7):999-1009.

7. Courjal F, Cuny M, Simony-Lafontaine J, Louason G, Speiser P, Zeillinger R et al. Mapping of DNA amplifications at 15 chromosomal localizations in 1875 breast tumors: definition of phenotypic groups. Cancer Res.1997; 57(19):4360-4367.

8. Champeme MH, Bieche I, Lizard S, Lidereau R. 11q13 
amplification in local recurrence of human primary breast cancer. Genes Chromosomes Cancer. 1995; 12(2):128-133.

9. Lammie GA, Peters G. Chromosome 11q13 abnormalities in human cancer. Cancer Cells. 1991; 3(11):413-420.

10. Zwijsen RM, Wientjens E, Klompmaker R, Van der Sman J, Bernards R, Michalides RJ. CDK independent activation of estrogen receptor by cyclin D1. Cell. 1997; 88(3):405-415.

11. Musgrove EA, Lee CS, Buckley MF, SutherlandRL. Cyclin D1 induction in breast cancer cells shortens G1 and is sufficient for cells arrested in G1 to complete the cell cycle. Proc Natl Acad Sci USA. 1994; 91(17):80228026.

12. Sutherland R L and Musgrove E A. Cyclin D1 and mammary carcinoma: new insights from transgenic mouse models. Breast Cancer Res. 2002; 4(1): 14-17.

13. Allred DC, Harvey JM, Berardo M, Clark GM. Prognostic and predictive factors in breast cancer by immunohistochemical analysis. Mod Pathol. 1998; 11:155- 168 PubMed .

14. Alle KM, Henshall SM, Field AS, Sutherland RL. Cyclin D1 protein is overexpressed in hyperplasia and intraductal carcinoma of the breast. Clin Cancer Res. 1998; 4:847-854 PubMed .

15. Pankaj G R, Norman P, Colin A P, Lee B, Alison A, Phil Q et al. High CCND1 amplification identifies a group of poor prognosis women with estrogen receptor positive breast cancer Int J Cancer. 2010; 127: 355-360.

16. Zhishuang L, Jingjing C, Qiong Y, Xiaojuan W, Aifeng P, Li L. Evaluation of CCND1 amplification and CyclinD1 expression: diffuse and strong staining of CyclinD1 could have same predictive roles as CCND1 amplification in ER positive breast cancers. Am J Transl Res. 2016; 8(1):142-153.

17. Cecilia A, Claudia L, Elin E, Karin J, Carl B, Fjällskog M L. High expression of cyclin D1 is associated to high proliferation rate and increased risk of mortality in women with ER-positive but not in ER-negative breast cancers. Breast Cancer Res Treat. 2017; 164:667-678.

18. Elsheikh S, Green AR, Mohammed AA, Grainge M, Paish CE, Lambros MBK, et al. CCND1 amplification and Cyclin D1 expression in breast cancer and their relation with proteomic subgroups and patient outcome. Breast Cancer Res Treat. 2008; 109(2):325-335.

19. Neuman E, Ladha MH, Lin N, Upton TM, Miller SJ, DiRenzo J et al: Cyclin D1 stimulation of estrogen receptor transcriptional activity independent of cdk4. Mol Cell Biol. 1997; 17:5338-5347 PubMed .

20. Zukerberg LR, Yang WI, Gadd M Thor A., Koemer F., Schmidt E et al: Cyclin D1 (PRAD1) protein expression in breast cancer: Approximately one-third of infiltrating mammary carcinomas show overexpression of the cyclin D1 oncogene. Mod Pathol.1995; 8:560-567 PubMed .

21. Buckley MF, Sweeney KJ, Hamilton JA, Sini RL, Manning DL, Nicholson RI et al: Expression and amplification of cyclin genes in human breast cancer. Oncogene. 1993; 8:2127-2133 PubMed.

22. Gillett CE, Lee AH, Millis RR, Barnes DM: Cyclin D1 and associated proteins in mammary ductalcarcinoma in situ and atypical ductal hyperplasia. J Pathol. 1998; 184:396-400 PubMed .

23. Ling-Ling G, Peng G, Ya-Guang W, Wen-Cheng J, Chun-Yan H, Hong L et al. Alteration of Cyclin D1 in Chinese Patients with Breast Carcinoma and its Correlation with Ki-67, pRb, and p53. Archives of Medical Research. 2007; 38 (8): 846-852.

24. Ravikumar G and Ananthamurthy A. Cyclin D1 expression in ductal carcinoma of the breast and its correlation with other prognostic parameters. J Cancer Res Ther. 2014; 10(3):671-5.

25. Lundgren K, Brown M, Pineda S, Cuzick J, Salter J, Zabaglo L et al. Effects of cyclin D1 gene amplification and protein expression on time to recurrence in postmenopausal breast cancer patients treated with anastrozole or tamoxifen: a TransATAC study. Breast Cancer Research. 2012; 14:R57. 